\title{
HOXC9 wt Allele
}

National Cancer Institute

\section{Source}

National Cancer Institute. HOXC9 wt Allele. NCI Thesaurus. Code C124119.

Human HOXC9 wild-type allele is located in the vicinity of $12 \mathrm{q} 13.3$ and is approximately 8 $\mathrm{kb}$ in length. This allele, which encodes homeobox protein Hox-C9, plays a role in the modulation of anterior-posterior axis formation. 